\title{
Family Businesses Can Help One Another
}

\author{
Theodore L. Waldron (Texas Tech University) \\ James C Wetherbe (Texas Tech University)
}

KEYWORDS: Marketing, Family Business, crisis management.

Measures to "flatten the curve" of the COVID-19 pandemic, such as limiting public gatherings and forcing the extended closure of non-essential businesses, have created one of the direst threats to small business survival in recent history. We've all heard stories of companies struggling to cover rent, to compensate employees, and to pay utilities, among many other issues, in the face of operating constraints and waning demand for their wares.

How would the pandemic-forced closure of your own favorite small businesses affect you - not only as consumers, but also as startup founders, family business owners and other entrepreneurs who may be experiencing similar struggles?

As consumers, we can all agree that we feel deep connections to our favorite small businesses and a sense of impending loss at the thought of losing them permanently. As entrepreneurs, it's easy to feel empathy and dread because it can so easily happen to us. This article offers some lessons on how we can help our favorite businesses to stay alive, using the case of the backpack and travel goods company TOM BIHN to show an example of how it is being done.

\section{A PERSONAL CONNECTION WITH}

\section{FANS}

TOM BIHN, which shares its founder's name, has been designing, manufacturing and selling renowned backpacks and related goods for the better part of 30 years in Seattle. The prospect of losing TOM BIHN to the COVID-19 pandemic has made its devoted consumer base uneasy, disheartened and disappointed -- feelings that indicate their profound emotional attachment to the company. The bottom line: TOM BIHN's consumers feel personally invested in what happens to the company's nearly 50 employees and their families during this difficult time.

A recent interview with Darcy Gray-one of TOM BIHN's owners and its CEO-suggests two possible reasons for this attachment.

One reason is that TOM BIHN represents a classic story of entrepreneurial success. The owners, Tom (founder), Darcy, and Nik (COO), overcame extreme hardships to build an international brand, including dropping out of school, caring for sick relatives, taking odd jobs, and living in poverty. This history is part of the company's narrative and it has endeared it to fans. Moreover, the company is renowned for the meticulous design and quality of its products, the personal nature of its connection to consumers, and the strong sense of community it instills among devotees.

Another reason is that TOM BIHN strives to be socially responsible. The company's owners consistently prioritize the well-being of their people over the size of their profits. It has made large investments in contactless sinks and air filtration systems to protect employees from COVID-19. The owners also engage in servant leadership, such as by fulfilling orders themselves to allow their employees to stay home. TOM $\mathrm{BIHN}$ has also converted production to make facemasks for health care professionals who need protective equipment.

TOM BIHN's consumers, like those with similar attachments to their favorite small businesses, have asked: What can we do to help them to survive the pandemic? This question may also resonate with business owners who want to encourage the support needed for their own businesses' survival.

Drawing from our expertise and from observing how its fan base has supported TOM BINH, we identify three actions that you can take to help your favorite small businesses to survive this difficult time. We call this the
Copyright $\odot 2020$ The Authors. Entrepreneur \& Innovation Exchange is published at EIX.org. This is an open access article under the terms of the Creative Commons Attribution-NoDerivs License, which permits use and distribution in any medium, provided the original work is properly cited and no modifications or adaptations are made. View EIX.org Authorship Terms at https://eix.org/terms
FamilyBusiness 
ECG approach, which means Educating others, C atalyzing support, and Getting involved to keep focal businesses going. The essence of the ECG approach is to mobilize a social movement that supports at-risk small businesses.

\section{EDUCATING OTHERS}

This action entails identifying, informing and motivating a group of like-minded consumers to support your favorite small business.

Social media can help you identify and rally a support group of like-minded consumers. Many companies maintain or participate in rich multi-platform conversations with their consumers. If you want to find others who share your concern, look to relevant threads and forums on Twitter, Facebook, Reddit, and companyowned websites.

Inform the support group of the situation facing the focal company. Using these online channels, lay out the problems facing the company, identify possible solutions, and establish a sense of urgency. Keep these points clear and concise, while remaining respectful of the pandemic-related issues others are experiencing in their personal lives.

Inspire the group to act on behalf of the focal company. Leverage the qualities you value most about the focal company to craft a shared motivation for the group and to call them to arms. Use slogans and acronyms that may be part of the company's history and lore.

Some leading members of TOM BIHN's consumer forum demonstrate this activism at work. These individuals have alerted other members of the challenges faced by the company. They've pointed out that TOM BIHN is using a skeleton crew to fulfill orders, manufacture new gear, and shift focus to producing protective equipment for healthcare professionals, all in the context of reduced sales. They also invoked shared passion for what TOM BIHN does to call for others to support the company in any possible way, such as by purchasing existing inventory.

Mobilizing a community of similarly interested stakeholders represents a crucial step in helping your favorite small business. To help keep the focal company from falling prey to the pandemic, there is strength in numbers.

\section{CATALYZING SUPPORT}

Call for others to shore up your favorite small business' cash flow, whether directly or indirectly - and do it yourself too. Whereas educating others is about priming support for the focal company, catalyzing support is about enacting that support.

As a gesture of direct support, you can buy the focal company's existing goods and services, purchase gift cards, or make donations. Avoid placing orders that might be difficult to fulfill while operations are constrained (e.g., out-of-stock backpacks). It might help to focus your financial support on employee relief funds (e.g., covering labor expenses) or on philanthropic activities (e.g., funding masks for health care professionals) to provide some income.

To give indirect support, lobby local, county, and state governments to provide the focal company with relief. Government entities have already provided tax credits to help small businesses keep paying their employees as their facilities remain closed, their sales flatline, and their cash reserves dwindle. Government officials may share the same passion that you do for the focal small business, so look for overlap on this front!

Leaders of TOM BIHN's support group purchased extra backpacks, travel bags, pouches and other gear for the express purpose of invigorating the company's cash flow while it balances order fulfillment and mask production with a severely reduced workforce and manufacturing capacity. Some have even looked into underwriting the costs of the masks that TOM BIHN has begun to produce. Others have purchased extra gift cards to use on products that will be replenished when production returns to full capacity or to hold as future gifts to relatives.

Ultimately, in the business world, cash is king. Infusing cash into your favorite small business, directly or indirectly, will go a long way in ensuring its survival.

\section{GETTING INVOLVED}

Put more skin in the game by working more intimately and intensively with your favorite company to solidify its foundations during the COVID-19 pandemic. Whereas catalyzing support is about infusing the focal business with cash through arms-length transactions like consuming or donating, getting involved is about enriching the business's foundations through more indepth interactions like investing or advising. 
You might consider making an investment into the company or organizing a group of investors. In the dire circumstances created by the pandemic, company leadership may be willing to offer an equity stake or board seats in exchange for a large infusion of cash from individuals or groups. Moreover, with the market down, the timing is good to invest in a business that you care about personally.

Assuming the owners are open to this sort of deal, make sure to specify its terms clearly and thoroughly. Make sure it works for both sides. An ambiguous investment agreement can create the potential for owners and investors to battle for control of the business, bringing harm to the very entity both sides originally sought to save.

If you don't want to invest money, invest your time. Offer your business expertise for free to the company, if the ownership welcomes the advice. For example, you can advise the company of opportunities to increase revenue, such as producing limited-edition products or holding auctions of rare unreleased products. Such options carry the benefit of commanding sizable premiums above the prices of normal versions of those products and of deferring the cost of production to future dates. Additionally, promoting temporary website-wide sales or bolstering value-added services, such as holding virtual classes that show the basics of how products are created, represent other ways to boost sales.

TOM BIHN's supporters have stepped in and contributed innovative, low-cost suggestions for generating revenue. They've suggested collaborating with other another popular organization in the industry on a limited-edition backpack, which would require prepayment for orders and defer production until normal operations resumed. Other ideas were to start a subscription service that would provide members with a new TOM BIHN organizer pouch or to hold virtual tours of its Seattle facility. Another fascinating proposal was to start a special works division within TOM BIHN that would produce limited-edition products supported by crowdfunding, much like an internal Kickstarter model.

Overall, finding ways to get more involved with your favorite small business during its time of need may cultivate additional opportunities for it to obtain lifesustaining cash.

\section{HOW OWNERS CAN LEVERAGE THE ECG APPROACH}

If your favorite small business happens to be the one you own, the ECG approach provides a potent tool for you to mobilize support from your fans.

Being proactive in this regard enables you to influence the forms of support your business receives, ensuring that support aligns with the company's values, identity and strategy. Social media venues, including forums run by your business, provide direct channels to educateconsumers and fans about the problems facing the business and to motivate them to act on its behalf. Such educational efforts play a crucial role in convincing some of your company's most ardent supporters to take the lead in catalyzing action and in getting involved.

One consideration may help when deciding whether you proactively seek support for your business. No matter how passionate consumers are about your business, you are the business's absolute best advocate! Even if your fan base takes the lead, tell them what you need to minimize misguided, unhelpful or counterproductive actions.

Darcy Gray took this approach when interacting with the leaders of the movement to support TOM BIHN and its employees, suggesting specific ways to help the company: "Share anything that comes to you - when we brainstorm here at work, we have a ton of ideas that don't go anywhere, but there's always a few ideas that turn out to be just what we needed."

\section{CONCLUSION}

How would the demise of your favorite small business affect you? By educating others, catalyzing support, and getting involved, you can help that business survive the pandemic. Enacting the ECG approach can be meaningful in ways that extend beyond increasing your favorite small business's durability.

As Darcy Gray put it when responding to the show of support for TOM BIHN: "Each day we've been reading the new posts in this thread and it's part of what keeps us going."

In their song Guerilla Radio, the rock band Rage Against the Machine once sang, "It has to start somewhere. It has to start sometime. What better place than here. What better time than now?" 
